\title{
Chromatin assembly from nucleosome to heterochromatin: the issue of DNA damage
}

\author{
Geneviève Almouzni \\ From Epigenetics and Chromatin: Interactions and processes \\ Boston, MA, USA. 11-13 March 2013
}

Studies concerning the mechanism of DNA replication and repair have advanced our understanding of the stable transmission through multiple cell cycles of a faithful genetic material. Recent work has shed light on possible means to ensure the stable transmission of information beyond just DNA and the concept of epigenetic inheritance has emerged. Considering chromatin-based information, key candidates have arisen as epigenetic marks including DNA and histone modifications, histone variants, non-histone chromatin proteins, nuclear RNA as well as higher-order chromatin organization. Thus, understanding the dynamics and stability of these marks following disruptive events during replication and repair and throughout the cell cycle becomes of critical importance for the maintenance of any given chromatin state.

We will present our most recent work on this topic, considering mostly histone variant dynamics during the cell-cycle and in response to DNA damage.

Published: 18 March 2013

\section{References}

1. Dunleavy EM, Roche D, Tagami H, Lacoste N, Ray-Gallet D, Nakamura Y, Daigo Y, Nakatani Y, Almouzni G: HJURP, a key CENP-A-partner for maintenance and deposition of CENP-A at centromeres at late telophase/G1. Cell 2009, 137:485-497.

2. Szenker E, Ray-Gallet $D$, Almouzni G: The double face of the histone variant H3.3. Cell Res 2011, 21:421-434.

3. Baldeyron C, Soria G, Roche D, Cook AJL, Almouzni G: HP1a recruitment to DNA damage by p150CAF-1 promotes homologous recombination repair. J Cell Biol 2011, 193:81-95.

4. Maison C, Bailly D, Roche D, Montes de Oca R, Probst AV, Vassias I, Dingli F, Lombard B, Loew D, Quivy JP, Almouzni G: SUMOylation promotes de novo targeting of HP1a to pericentric heterochromatin. Nature Genet 2011, 43:220-227.

5. Cook AJL, Gurard-Levin ZA, Vassias I, Almouzni G: A specific function for the histone chaperone NASP to fine-tune a reservoir of soluble $\mathrm{H} 3-\mathrm{H} 4$ in the histone supply chain. Mol Cell 2011, 44:918-927.

Laboratory of Nuclear Dynamics and Genome Plasticity, UMR 218 CNRS/ Institut Curie, Research Center, 26 rue d'Ulm, F-75248 Paris cedex 05, France
6. Ray-Gallet D, Woolfe A, Vassias I, Pellentz C, Lacoste N, Puri A, Schultz DC, Pchelintsev NA, Adams PD, Jansen LE, Almouzni G: Dynamics of histone $\mathrm{H} 3$ deposition in vivo reveal a nucleosome gap-filling mechanism for H3.3 to maintain chromatin integrity. Mol Cell 2011, 44:928-941.

7. Maison C, Romeo K, Bailly D, Dubarry M, Quivy JP, Almouzni G: The SUMO protease SENP7 is a critical component of pericentric heterochromatin to ensure local HP1 enrichment. Nature Struct Mol Biol 2012, 19:458-460.

8. Szenker E, Lacoste N, Almouzni G: A developmental requirement for HIRAdependant $\mathrm{H} 3.3$ deposition revealed at gastrulation in Xenopus. Cell Rep 2012, 1:730-740.

doi:10.1186/1756-8935-6-S1-015

Cite this article as: Almouzni: Chromatin assembly from nucleosome to heterochromatin: the issue of DNA damage. Epigenetics \& Chromatin 2013 6(Suppl 1):015.
Submit your next manuscript to BioMed Central and take full advantage of:

- Convenient online submission

- Thorough peer review

- No space constraints or color figure charges

- Immediate publication on acceptance

- Inclusion in PubMed, CAS, Scopus and Google Scholar

- Research which is freely available for redistribution
C Biomed Central
C Biomed Central

() 2013 Almouzni; licensee BioMed Central Ltd. This is an Open Access article distributed under the terms of the Creative Commons Attribution License (http://creativecommons.org/licenses/by/2.0), which permits unrestricted use, distribution, and reproduction in any medium, provided the original work is properly cited. 